\title{
Study on Internationalization of Higher Education Development in China
}

\author{
Miao Shang ${ }^{1, a^{*}}$, Chunfei Ju, ${ }^{1, b}$ and Jun Yang ${ }^{3, c}$ \\ ${ }^{1}$ Mechanical and Electrical Technology Department, Xijing University, Xi'an, China

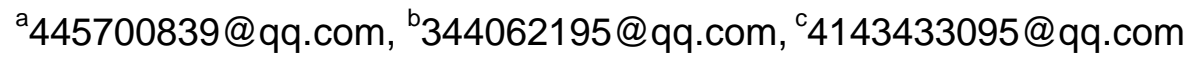

Keywords: High education; Transnational education; Output of education; Elite; Popularity

\begin{abstract}
In under the economic globalization impetus, the higher education internationalization already became an irresistible tendency. Higher education is to spread across the globe. Higher education school idea, supplies pattern and operation way which are in constant change. In this paper, the made of higher education connotation has been the introduction; The characteristic of higher education development has been carried on showing; The reason of higher education transnational development has been carried on analysis. Our country higher education development presented many new characteristics. The higher education internationalization characteristic and the tendency that have brought the huge influence and the impact for the various countries' education and the economical and society's development. Not only our country higher education internationalization needs the outstanding person and the popularity, also our country higher education needs to specialize with the practical application. Our country higher education internationalization needs to make more services for the various countries' peace stability, economical development and global harmony.
\end{abstract}

\section{Introduction of Higher Education}

Higher education is built on general education on the basis of professional education. Higher education including specialist, undergraduate and graduate. Higher education can be divided into full-time education and amateur education, face-to-face-to-education and non-education. Higher education schools in the form of education and non-school education. Higher Education Gross Enrollment Ratio an show Fig. 1.

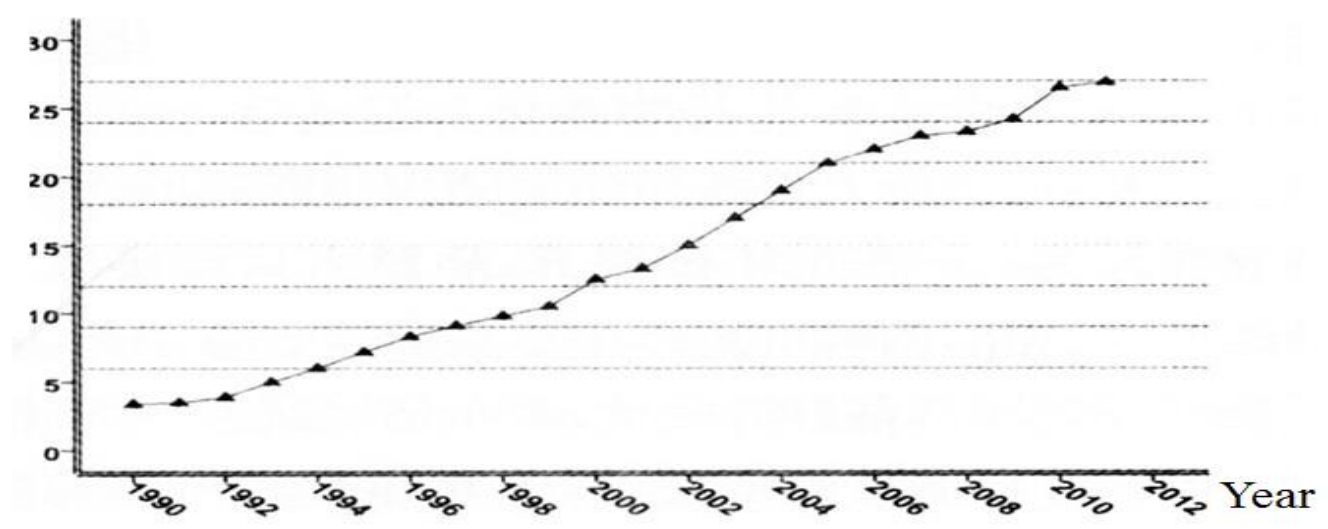

Figure 1. Higher Education Gross Enrollment Ratio

The higher education in China including college in university and college graduate, and staff University, Central Radio and TV University. Tertiary education places mainly refers to the full-time tertiary education. The major tertiary education places studied college and university education. Higher education is an emerging interdisciplinary. Traditional education of the object of study in general limited ordinary primary and secondary education as the rapid development of science and technology, since the 1950s, and the higher education project has developed rapidly. The higher education system and a variety of forms. Of higher education and the teaching process is complicated. 
The traditional education has been unable to meet this requirement. With the rapid development of higher education, higher education and research at the national doctrines have flourished.

Higher education is a general culture of scientific knowledge-based professional education. Higher Education to Train is the economy and the superstructure of the High expertise. Higher Education object is a young university students. Higher education content is the necessary foundation for the professional knowledge, skills, and professional knowledge, skills, rather than the general culture of scientific knowledge. Higher education teaching methods should be adapted to the students the physiological and psychological characteristics. Higher education in scientific research into the teaching process as an integral part of the school and the important function.

\section{Characteristics of Development of Higher Education}

Higher Education object is a young university student. Higher education is to explore the truth and the development of knowledge which are generated and developed. The mediaeval university through the teachers and pupils in a very narrow range of flow to broken through the national boundaries and geographical constraints, promote the dissemination of knowledge and exchange. In the modern university since the birth of higher education international exchange of cultural interchange and cooperation between scientific research. Academic strength, as well as the search for truth is to promote the flow of higher education. The pursuit of knowledge and the dissemination of culture is the most fundamental education exchange.

With the development of the economy, political forces gradually exceeding the cultural forces driving the development of higher education to internationalize the leading force. Almost all developed countries, its International Education projects funded by the Government to provide stable funding support and management, to accept the political and diplomatic assessment of the international exchanges in higher education and the country's fundamental political and diplomatic policies of a country to promote its diplomatic policies and values of the tool. In the 1980s, the impact of economic globalization, countries political, economic, cultural, and other fields have radically changed. The Internationalization of Higher Education showed the ever new and different characteristics.

Economic Interests of Quest to Become High Impact of Education for Main Factors Internationalization. In the global economy under the effect of the evolution of the education services education industry Higher education has gradually become the system of trade in services of an important commodity. Market concepts are constantly strengthened, economic factors to the acceleration of the posture to infiltrate into the field of education. In the past, cultural and political internationalization of higher education in the dominant power in the market is being gradually weaken or even replace.

Since the British first to profit for the purpose of changing the students since the policy began in Commonwealth countries have followed suit. Since then, the United States, Germany, France, the Netherlands, even in Southeast Asia, Singapore, Malaysia and Hong Kong, has also been changed to foreign students undertaking full funding or preferential charging policy, the students education and education services, and commercialization. States was the main driving force behind the Internationalization of higher education came out of economic interest and damages. Higher education has become an international free trade of commodities, it is a private interests rather than public accountability, and these concepts are affecting the free trade of the background. Contemporary these strong views of higher education in the field of market and lead to commercial strength in higher education had a legitimate and even to the reign of status.

Higher Education Services Provide Body of Diversification. Svava bjamason had pointed out that the provision of transnational services for higher education of the four types of body are: private non-profit education providers, private for-profit education providers, public education, as well as the University of corporatization. In addition to this the repatriation of the precarious some 
knowledge-intensive firms, various international organizations could participate in the higher education services across borders.

The traditional non-profit University on the one hand, in order to promote the development of science and technology, enhance cultural mutual recognition of degrees and to continue to strengthen cooperation for research and exchange; on the other hand because of the reduction in government funding for education, to encourage schools to include building branch campuses overseas, mutual recognition of credits, and local education institutions in the form of cooperation to overseas expansion into the ranks of the internationalized.

At the same time, the increasing number of international organizations in higher education services across borders in the development process of the play an increasing role. Such as: the United Nations Educational, Scientific and Cultural Organization (UNESCO) - direct commitment to the international exchange of higher education and communication. The Organization for Economic Cooperation and Development (OECD), the World Trade Organization (WTO), the European Union and other international organizations are actively involved in the promotion, coordination of transnational educational activities.

Higher Education Resources in Form of Movement Diversification. At present, not only in the form of Internationalization of higher education focused on academic research and the teaching of the movement of persons, but also to the tertiary level, internal hierarchy - Education projects and institutions in the transnational flow of the hierarchy. Branch campuses overseas (branchcampus), Joint courses (franchises), credits, as well as network or interchangeable (articulation) remote learning, and other new forms of cooperation, including not only the transfer of knowledge, but also the flow of funds. For example, the British University of Nottingham respectively in 2000 and 2005 in Malaysia and China established the UC Berkeley and independent set of Sino-foreign cooperative educational bodies.

Development of Uneven Nature of Higher Education. Transnational higher education established output side also has entered the parties and that the developed countries, especially English-speaking countries of the various education services projects, institutions and the resources of the main exporters of EU in part of the larger countries such as Germany and France, followed by developing countries is largely education input. The least developed countries as part of the educational output party, control of transnational higher education projects and institutions as well as for the international accreditation or quality assurance agencies in transnational education in absolutely dominant position, and from which to obtain the majority of the economic benefits. The Western academics enshrined in the "world academic centers and the distinction between edge" in higher education in the global competition has become more complex.

\section{Analysis of Reasons for Development of Transnational of Higher Education}

To the movement of persons, Project flows and the flow of educational institutions for the main characteristics and forms of transnational and students in higher education, education, international academic exchanges, international cooperation and scientific research, constitute a major framework for Internationalization of higher education and the content. 2 transnational development of higher education has both cultural exchanges and the demands of the development of education itself, there are political and economic interests. From the globalization of the process of development as well as the history of the development of the higher education, higher education is a transnational factor such as a result. Push-pull theory is often used to research staff personnel studying abroad for Sociological Analysis. According to this theory, study abroad is because of its own internal unfavorable factors the promotion and external factors of strong pull together the results. The view: impact of individual ahbach make going abroad to study the decision-making of thrust include: the possibility of access to scholarships, poor educational facilities, appropriate education facilities and research and the lack of equipment, did not have access to the local universities, are not suitable for the socio-economic and political environment, foreign places in the labor market, the value-added, recognizing that the 
various existing educational tradition of inadequate; and impact of individual make going abroad to study the decision-making of pull mainly include: the provision of scholarships to international students the possibility, quality education resources, available advanced education and research equipment, appropriate socio-economic and political environment, there were opportunities for international life experience and so on. 1 The movement of persons in most cases by individuals, transnational higher education is far more complex. We can learn from the government level, the institutions as well as individual level, a comparative analysis of higher education-exporting countries and importing countries in the development of tertiary education in transnational drivers of the difference.

Impact of Government. At the government level, whether they are exporters of higher education or higher education enter country, the implementation of the transnational higher education are accessible by introducing the mechanism of competition and the operation of the new forms of philosophy, and projects and for the achievement of its reform, the promotion of higher education traditional educational systems international purposes. But higher education input and sending countries in the development of higher education in transnational aspects or whether there is a significant difference.

In the economic sphere of higher education: exporting countries, transnational higher education may be its bring considerable economic revenue that could be enhanced in their countries in the world in the education market competitiveness, the Government make up for the shortcomings of the input of funds can also take this to absorb the talents required resources. Enter the country for higher education, transnational higher education can help increase their supply capacities of the higher education system and to promote the school sponsoring body and the input of funds for pluralism, reducing the brain and the loss of foreign exchange, attract foreign investment and foreign high-quality education resources.

In the cultural and social aspects of higher education: exporting countries, transnational higher education can achieve its popularization of culture, values, and for the purpose of Language can help resources for education as a result of social changes of excess or cause the educational structure of the problem of imbalance. The high education such as importing countries to implement transnational higher education can improve enrolment ratios, meet their own systems cannot meet the demand for higher education of citizens, promotion of multi-cultural development.

Higher Education in Own Development. From the layer of institutions, transnational higher education is output and the expansion of both institutions $\$^{\wedge}$ international exchange and cooperation in the important means that the two sides agreed to cooperate in the implementation of transnational higher education, could provide a boost to cooperation in research, exchange of teachers, students, including exchange of aspects of cooperation and exchange.

In economic aspects: the output of higher education institutions are concerned, the multinational implementation for higher education and its direct economic benefits that effective compensate for the reduction in funding for education from the gap, while through cooperation institutions to open up direct source of channels, to attract more foreign students at their own expense. For higher education institutions to enter said that the implementation of the transnational higher education can also bring additional sources of income, can do so at a low cost for the curriculum, teaching materials and other educational resources.

In the academic institutions of higher education in the output to implement transnational higher education students can optimize the structures and increase the flow of teachers and students the opportunity to contribute to the development of new courses and to the promotion of existing curricula internationalization of the expansion of the network of academic cooperation in research and development opportunities and so on. Enter the institutions of higher education in that transnational higher education can with foreign institutions to enhance the image of the schools to help teachers in the absence of experience and expertise in the new areas for development and promote the development of professional and academic disciplines, can introduce new courses, and personnel training modes and advanced management experience. 
Personal Development. From the individual level, since the transnational higher education so that students go abroad or part-time abroad can be obtained at foreign universities diploma or degree, learning costs relative to go abroad to be much lower, and foreign universities of the diplomas and degrees in the local accreditation, high returns to learning rate (including employment, wages and fluidity, etc.) than from local universities for the diplomas and degrees to high, added to the local institutions and require fewer opportunities for enrolment high and entered the transnational higher education projects or institutions more easily and so on various economic, social and cultural factors have contributed to the students select Accept transnational higher education.

\section{Direction of Development of Higher Education International for China}

As our country's rapid economic development, as constantly improve the living standards of the people, the higher education in China is the need to move toward elite and eventually to the direction of development. At the same time, in the course of economic globalization, driven by higher education internationalization has become an irresistible trend. Higher education is to spread across the globe. Higher education academic ideals, supply mode and mode of operation of the constant change. The development of higher education in different from that in the past the new characterist0ics. The Internationalization of higher education, there is an urgent need for a breakthrough in a single cultural exchange, it is necessary to establish the promotion of global economic development the multiple goals. The characteristics of the Internationalization of higher education and trends, to national education and economic and social development has brought about tremendous influence and impact. The Internationalization of higher education requires not only the kind of elitism and popular, but also to professionalize and utility. The Internationalization of higher education needs to do more services for national peace and stability, economic development and the Global Harmony.

\section{References}

[1] G.S.Yi: University Chinese-Foreign Cooperation in Running Schools Mode and Operation Mechanism of Research (Shanghai University Publishing House, China 2007.)

[2] J.B.Wang, H.T.Yang::New Field of Overseas Investment-New Trend of Transnational Higher Education (DongYue Review, China, 2012)

[3] B.C.Ji:Our Country's Higher Education Scale Forecast Analysis in 2020, Vol. 1 (2011) No. 1, p. 305.

[4] Verbik L, Merkley C: Intematinal Branch Campus - Models and Trends, Observatory on Borderless (Higher Education Report, China, 2006).

[5] L.J.Guo: Under Globalization of Transnational Higher Education -Point of View, Problems and China's Response (China Social Sciences Press, China, 2009)

[6] H.Y.Liu: U DP Proportion Higher Education and Social Policy Research, Vol. (2012), P. 27-28.

[7] Benoit Minogue: Higher Education Spending and Output-Complexity of Relationship, Peking University Education review, Vol. 2 (2013), 60.

[8] Henry m. levin. Education How to Adapt to Future-Background of American Education, Peking University Education Review, Vol. 2 (2013), p. 2-3.

[9] Y.L.Xie : Soul of European Universities Classification, Comparative Education Research, Vol.4 (2010), p. 45.

[10] G.P.Feng: Transnational Education-International Comparative Study (Shanghai People's Publishing House, China ,2010) 
[11]X.J.Guo: Transnational Education Development Concept and Strategy (Stanford university press, China, 2008) 